\title{
Paleofacies of Eocene Lower Ngimbang Source Rocks in Cepu Area, East Java Basin Based on Biomarkers and Carbon-13 Isotopes
}

\author{
Elok A Devi ${ }^{1}$, Faisal Rachman ${ }^{2}$, Awang H Satyana ${ }^{3}$, Fahrudin ${ }^{1}$ and Reddy Setyawan ${ }^{1}$ \\ ${ }^{1}$ Geological Engineering Department, Diponegoro University, Indonesia \\ ${ }_{2}^{2}$ Joint Operating Body Pertamina-PetroChina East Java (JOB P-PEJ), Indonesia \\ ${ }^{3}$ Special Task Force for Oil and Gas (SKKMIGAS), Indonesia
}

Submission: April 04, 2018; Published: April 16, 2018

*Corresponding author: Elok A Devi, Geological Engineering Department, Diponegoro University, Indonesia, Email: elokannisadevi@gmail.com

\begin{abstract}
The Eocene Lower Ngimbang carbonaceous shales are geochemically proven hydrocarbon source rocks in the East Java Basin. Sedimentary facies of source rock is important for the source evaluation that can be examined by using biomarkers and carbon-13 isotopes data. Furthermore, pale geography of the source sedimentation can be reconstructed. The case study was conducted on rock samples of Lower Ngimbang from two exploration wells drilled in Cepu area, East Java Basin, Kujung-1 and Ngimbang-1 wells. The biomarker data include GC and GC-MS data of normal alkanes, isoprenoids, triterpanes, and steranes. Carbon-13 isotope data include saturate and aromatic fractions. Various cross plots of biomarker and carbon-13 isotope data of the Lower Ngimbang source samples from the two wells show that the source facies of Lower Ngimbang shales changed from transitional/deltaic setting at Kujung-1 well location to marginal marine setting at Ngimbang-1 well location. This reveals that the Eocene pale geography of the Cepu area was composed of land area in the north and marine setting to the south. Biomarkers and carbon-13 isotopes are powerful data for reconstructing pale geography and Paleofacies. In the absence of fossils in some sedimentary facies, these geochemical data are good alternatives.
\end{abstract}

\section{Introduction}

Tertiary producing North East Java Basin, sourced by Ngimbang carbonaceous shales, was formed during the Eocene as the early synrift stage [1]. Mid-Late Eocene synrift to late synrift Ngimbang shales, coals, and coaly shales are proven source rocks of East Java. All oils in the East Java Basin are consistent with deposition of the source rock in a fluviodeltaic to near shore marine environment Basin $[2,3]$.

There is no recent or detail publication about Paleofacies of Ngimbang source rocks in Cepu Area; therefore, the main objective of this study was conducted is to explain the Paleofacies of Lower Ngimbang source rock in Cepu Area, East Java Basin. The knowledge of source Paleofacies is important for evaluation and reconstruction of pale geography of the source rock and it's potential. The study employed biomarkers and carbon-13 isotopes data to identify Paleofacies. It has been recognized that biomarkers in oils and rock extracts reflect depositional environment [4-6].

Biomarkers are molecular fossils derived from living organisms, and these complex compounds are composed of carbon, hydrogen, and other elements. Biomarkers show little or no change in chemical structure from their parent organic molecules in living organisms [5]. Biomarkers are very useful due to

Their complex structures, revealing precise information about the depositional origins. Whereas, the carbon-13 isotope is chosen because of its stability and accuracy for measurement [4]. Thus, biomarkers and carbon-13 isotopes are used to achieve the main objectives of this study.

\section{Geologic Setting}

Geologic setting of East Java consisting of Northern Platform, Central Deep, and Southern Uplift (Figure 1), and North East Java basin is located on the southeastern margin of a stable Sundaland micro continent. The basin is bounded by Karimun Java arch to the west, Masalembo High to the north, Doang High to the east and volcanic arc to the south. The basin was initiated at mid- Cretaceous age by collision between microplates at the southeastern margin of Sundaland. This collision created a suture zone between microplates and later on becomes a 


\section{Recent Advances in Petrochemical Science}

structural grain lineament of half and graben in North East Java Basin. The extensional phase that creates graben system in North East Java Basin began in Palaeogene to Early Neogene time. It is interpreted to be formed by slab roll-back system between Australian to Eurasia-Sundaland plate subduction. The compressional phase has occurred during Neogene to the present time as an implication of Indian oceanic plate subduction to the south of Java Island, a westward stress due to ButonTukang Besi and Banggai-Sula collision to the western part of Sulawesi, and due to large sinistral strike slip RMKS (Rembang-MaduraKangean-Sakala Fault [2].

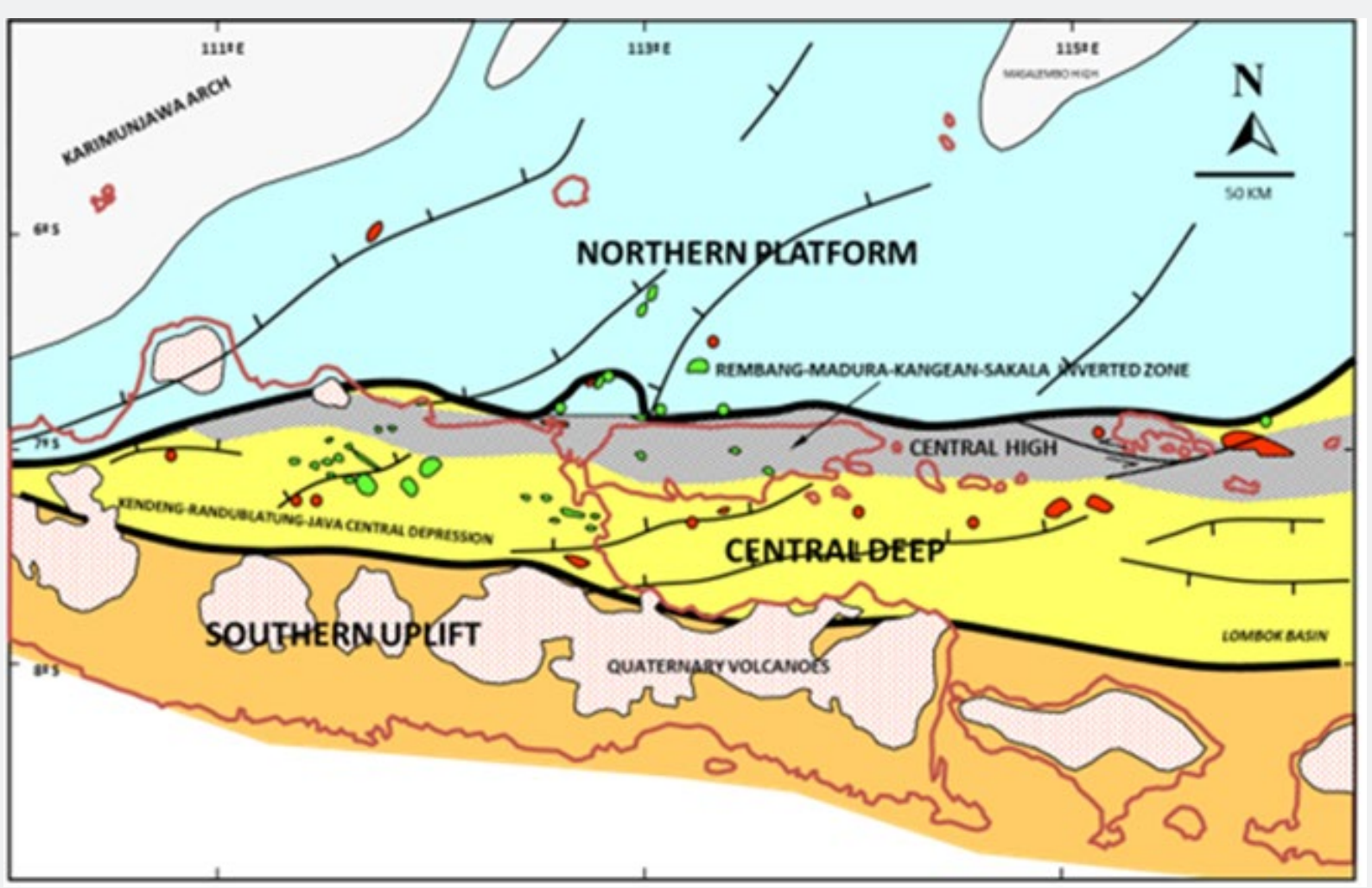

Figure 1: Geologic setting of East Java [7].

Regional stratigraphy in the study area began with Ngimbang Formation marking the onset of Tertiary sedimentation in the East Java Basin with the distribution of Lower Ngimbang Formation sediments controlled by an existing pre-Tertiary configuration of roughly east-west oriented half grabens, rotated later as SW-NE oriented grabens. The Lower Ngimbang Formation comprises lacustrine, fluviodeltaic, and marginal sediments filling these fault-controlled basement lows during the Middle-Late Eocene. These units are important potential hydrocarbon sources in the basin as geochemically proven by oils in the Mudi Field, Cepu Fields, and the residual oil in the Kembang Baru wells. Ngimbang Formation sedimentation continued throughout the Early Oligocene with the deposition of Upper Ngimbang Formation, comprising transgressive shales and claystone and minor platform carbonates and rare low relief carbonate build-ups [7-9].

During the Late Oligocene, Kujung Formation carbonates were deposited over the Ngimbang Formation and on existing pre-Tertiary basement highs with reefal build-ups developed throughout the East Java area. Patch reefs developed along the central basin edges with pinnacle-type reefs occurring in the isolated highs of deeper water area.

The Early Miocene-aged Tuban Formation also generally marks the change from the predominantly carbonate deposition of the Kujung Cycle to mostly fine grained siliciclastics deposited during a major regressive phase. A Tuban shelf edge was located approximately in the position of the present day North Java coastline. During the Middle Miocene, the Ngrayong Formation consisting of mainly shelfal shales with minor interbedded sandstones and claystones was deposited over the remaining few isolated Tuban Formation carbonate build-ups marking the end of reef growth. Deep water turbiditic sandstones were also locally deposited throughout the area.

Clastic sedimentation continued throughout the Late Miocene with the deposition of deep water claystones of the Wonocolo Formation, prior to a major tectonic compressional event that caused widespread uplift and basin inversion at the end of Miocene times. This tectonic event leads to a series of regressive and transgressive sedimentary cycles throughout the PlioPleistocene which were largely controlled by the emergence of the southern volcanic arc [2]. 


\section{Data and Methods}

This study used biomarkers and carbon-13 isotopes data to determine Paleofacies and reconstruct the source sedimentation pale geography of Lower Ngimbang Formation as the source rocks in the East Java Basin. The case study was conducted on the rock samples of Lower Ngimbang from two exploration wells drilled in Cepu area, East Java Basin, namely Kujung- 1 and Ngimbang-1 wells. The biomarker data were obtained from GC and GC-MS analysis of normal alkanes, isoprenoids, triterpanes, and steranes (Figure 2). Carbon-13 isotope data include saturate and aromatic fractions.

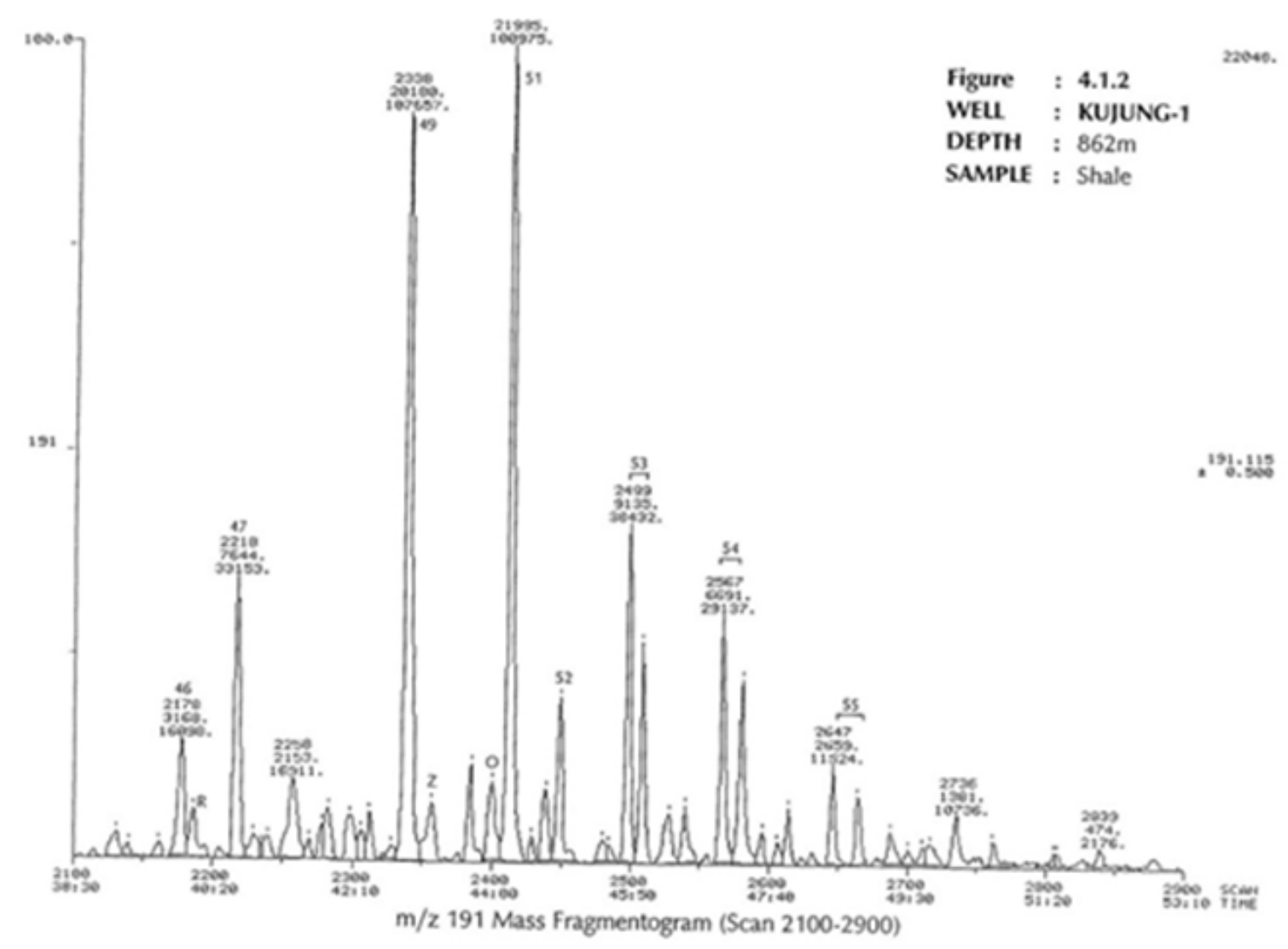

Figure 2: GCMS chromatogram m/z 191 of Ngimbang Formation at Kujung-1 Well.

The biomarkers which were found in the organic matters of Lower Ngimbang source rock can show the facies changes and reconstruct the pale geography. Organic matter accumulating in source sediments possesses distinctive biochemical characteristics inherited from a specific combination between the organisms and the depositional environments where these source sediments were deposited (source or organic facies). Every item of organic matter deposited in a specific depositional environment/source facies developed a specific biomarker.

Biomarkers and carbon-13 isotopes in source facies interpretation were carried out by analyzing various geochemical cross plots. Cross-plots (i.e. plot of one diagnostic biomarker ratio versus another ratio) are another diagnostic means frequently used in oil geochemistry for oil-oil correlation and determination of oil source and depositional environment.

\section{Result and Discussion}

\section{Paleofacies of eocene lower ngimbang}

This study showed that from Kujung-1 and Ngimbang-1 wells penetrating to Lower Ngimbang source rocks, the precise interpretation of the Paleofacies can be achieved through detailed examination of biomarkers from the source rocks although there is no biostratigraphic data. Gas chromatography (GC) and gas chromatography mass spectrometry (GCMS) fingerprints can indicate certain types of source facies by using cross-plots of biomarkers.

\section{Clues from biomarkers}

The pristane/phytane ratio has been used as an indicator of depositional environment with a low specificity due to the interferences by thermal maturity and source inputs. The results of this study show that pristane/phytane ratios mostly greater than 2.0 and pristane/n-C17 ratios are roughly similar, indicating deltaic/transitional with terrestrial input at Lower Ngimbang (Kujung-1 Well) and deposition in a relatively sub-oxic to oxic environment. On the other hand, at Ngimbang-1 Well, all pristane/phytane ratios less than 2.0 and pristane/n-C17 ratios are roughly similar which are interpreted as marginal marine source facies and deposition in sub-oxic to anoxic environment (Figure 3). 


\section{Recent Advances in Petrochemical Science}

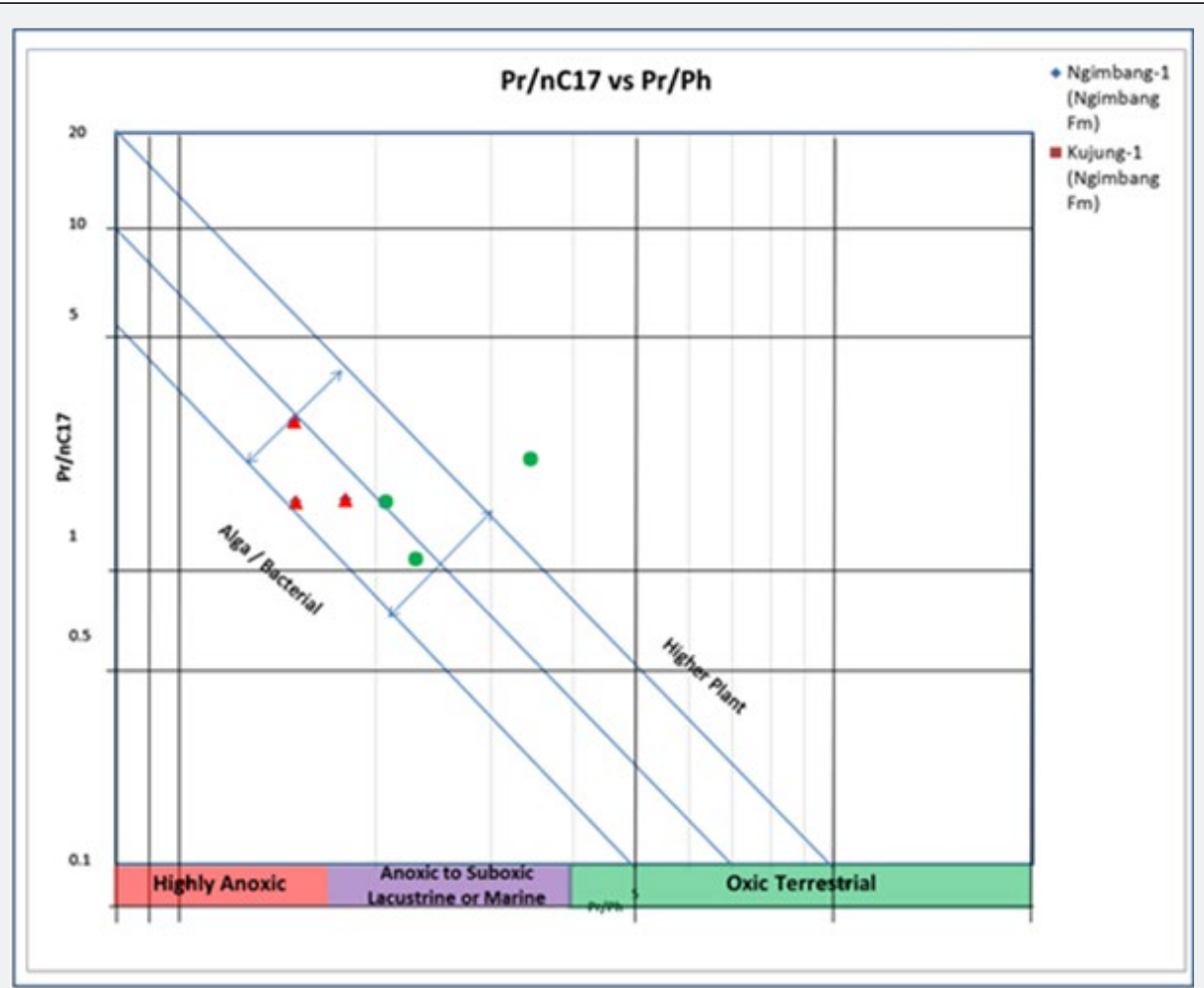

Figure 3: Plot of pristane/n-C17 versus pristane/phytane showing the depositional environment and the conditions of the studied rock samples.

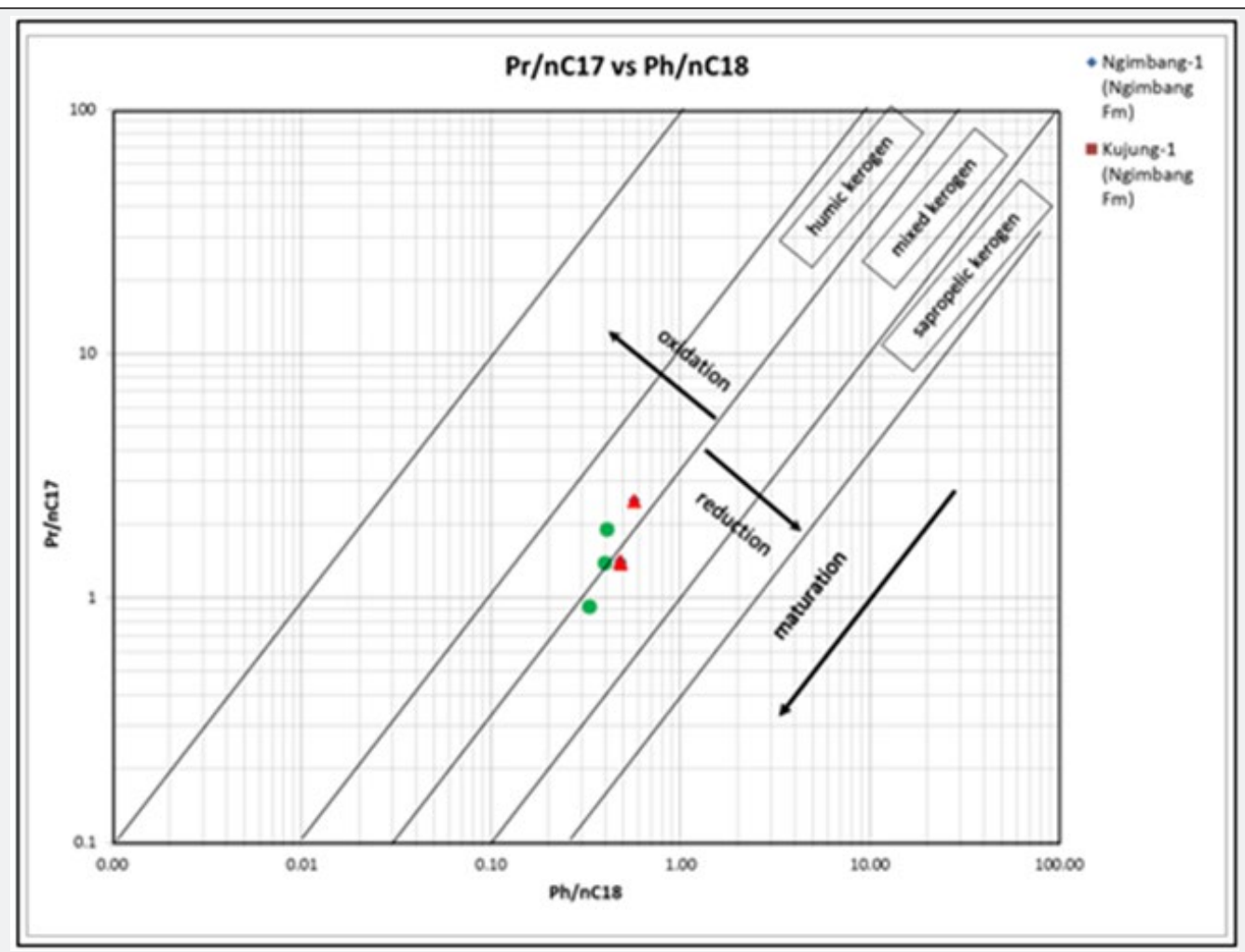

Figure 4: Plot of pristane/n-C17 versus phytane/n-C18 showing the organic sources and maturation of the studied rock samples. 


\section{Recent Advances in Petrochemical Science}

The resultant ratios pristane/n-C17 and phytane/n-C18 (isoprenoids/n-alkanes) of Lower Ngimbang source rocks in Kujung- 1 and Ngimbang- 1 Wells range from 0.48 to 0.57 and 0.33 to 0.41 respectively. The ratios reflect that most of Lower Ngimbang source rocks were from humic and mixed kerogen (organic facies) deposited under transitional environment (Figure 4).
Furthermore, the total hopane/sterane ratio is proven to be one of the best discriminators between marine and non-marine environment in several studies. In this case study, Kujung-1 Well show high hopane/sterane ratios which are typical of predominantly sub-oxic to oxic terrestrial influence, whereas low hopane/sterane ratios at Ngimbang-1 Well show anoxic to sub-oxic with primarily algal input (Figure 5).

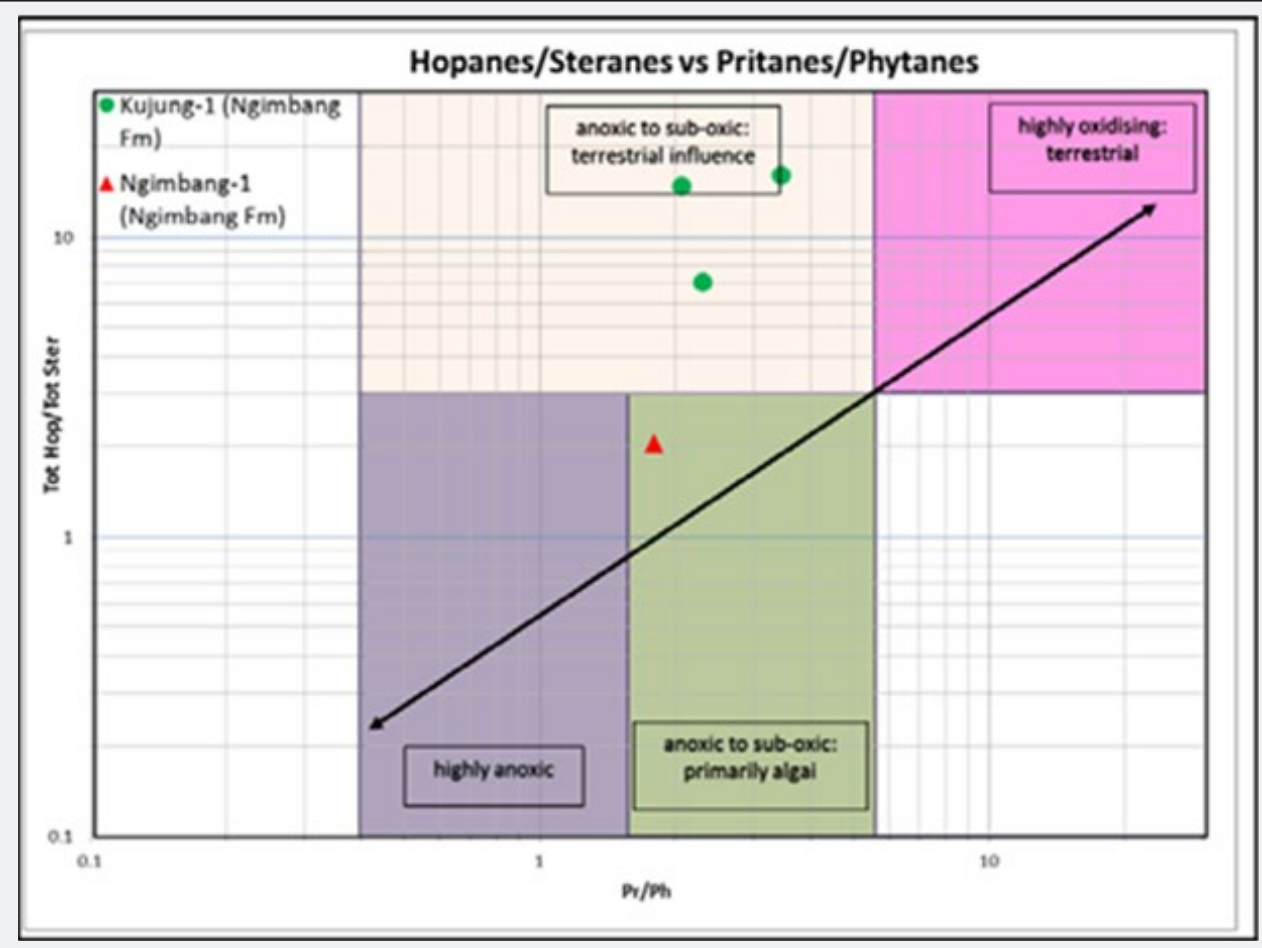

Figure 5: Plot of hopane/sterane versus pristane/phytane showing the organic source input and the environment condition of rock samples.

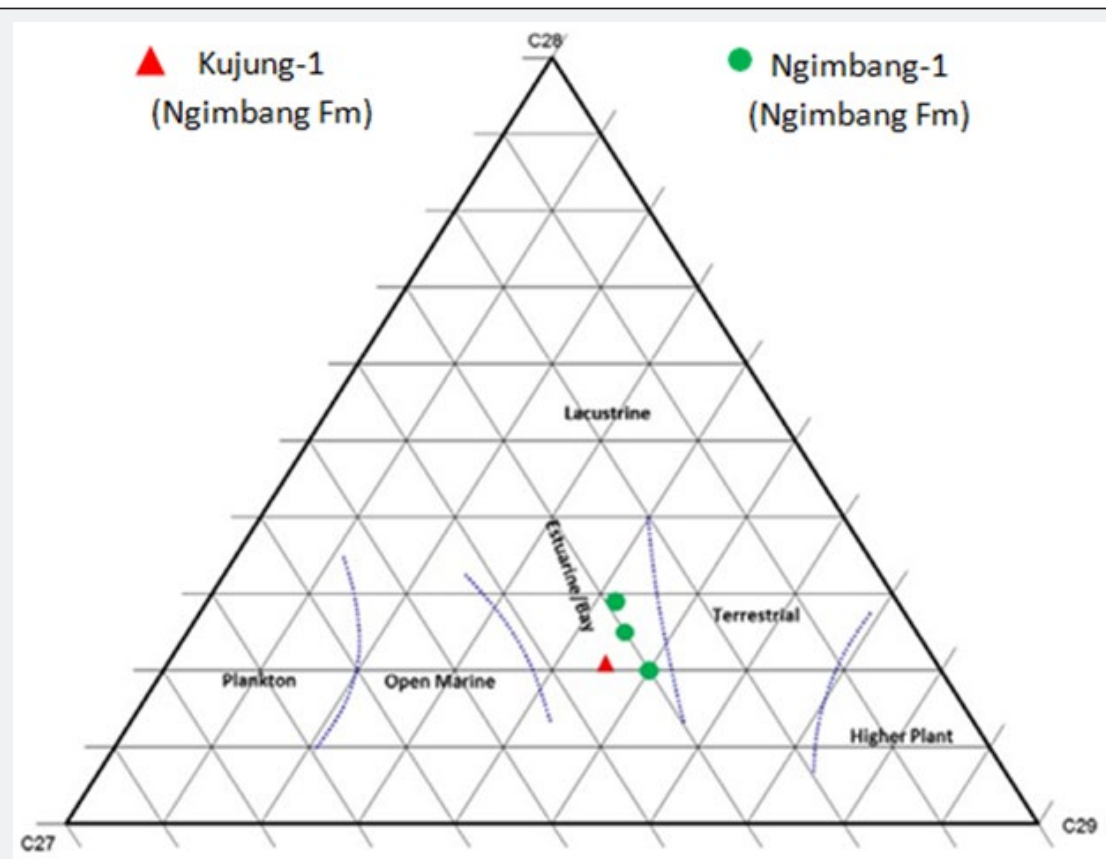

Figure 5: Ternary diagram of $\mathrm{m} / \mathrm{z} 217$ sterane C27-C28-C29 showing the depositional environment of the rock samples. 
The ternary diagram of m/z 217 sterane C27-C28-C29 also shows the changes of Paleofacies from Kujung-1 and Ngimbang-1 Wells which are all Lower Ngimbang sources with a predominant estuarine/bay depositional environment, but Ngimbang-1 Well is more marine than Kujung-1 Well (Figure 6).

\section{Clues from isotope carbon-13}

Cross-plot of carbon-13 isotope shows saturate versus aromatic fractions ratio from Kujung-1 Well are deltaic to marginal marine environment, while Ngimbang-1 Well are more marine (Figure 7).

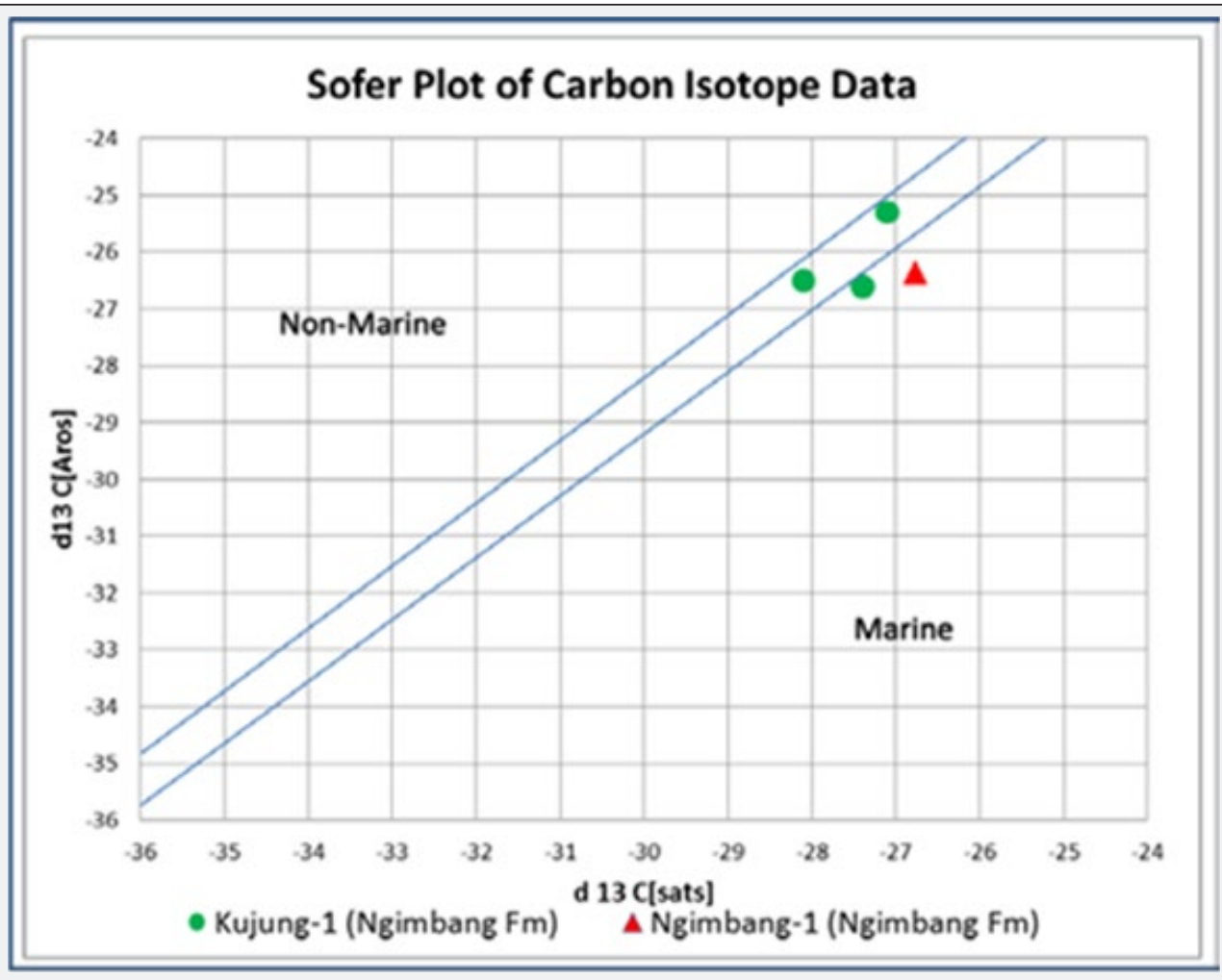

Figure 7: Plot of carbon-13 isotopes showing the depositional environment of the rock samples.

\section{Pale geography reconstruction}

From various cross plots of biomarker and carbon-13 isotope data of the Lower Ngimbang source samples, it reveals that the Eocene pale geography of the Cepu area was composed of land area at the Kujung-1 well location and marine setting at Ngimbang-1 well location.

\section{Conclusion}

Biomarkers preserved in the organic matters of Lower Ngimbang source rock can reflect the pale geography setting and the source facies where the source facies of Lower Ngimbang shales changed from transitional/deltaic setting at Kujung- 1 well location to marginal marine setting at Ngimbang- 1 well location. Therefore, it also reveals that the Eocene pale geography of the Cepu area was composed of land area in the north and marine setting to the south.

\section{Acknowledgment}

We thanked the reviewer and the editor of GCGE2017 for their constructive suggestions.

\section{References}

1. Ardhana W (1993) A depositional model for early miocene ngrayong formation and implications for exploration in the east java basin. Indonesian Petroleum Association 1: 395-443.

2. Satyana AH, Purwaningsih MEM (2003) Geochemistry of the East Java Basin: New Observations on Oil Grouping, Genetic Gas Type and Trends of Hydrocarbon Habitats. Indonesian Petroleum Association 1: 1-23.

3. Satyana AH (2013) The power of oil biomarkers for regional tectonic studies: how the molecular fossils impact exploration ventures - case studies from Indonesia. Indonesian Petroleum Association, Indonesia.

4. Hunt JM (1996) Petroleum geochemistry and geology. In: $\left(2^{\text {nd }}\right.$ edn), WH Freeman and Company, New York, USA.

5. Peters KE, Moldowan JM (1993) The Biomarker Guide: Interpreting molecular fossils in petroleum and ancient sediments. Englewood Cliffs: Prentice-Hall, Inc, USA.

6. Peters KE, Walters CC, Moldowan JM (2005) The Biomarker Guide. In: $\left(2^{\text {nd }}\right.$ edn $)$, Cambridge University Press, Cambridge, USA, Volume 1.

7. Satyana AH, Darwis A (2001) Recent significant discoveries within oligo-miocene carbonates of the east java basin: integrating the petroleum geology. Proc on Indonesian Association of Geologists (IAGI), Indonesia, p. 42-46. 


\section{Recent Advances in Petrochemical Science}

8. Doust H, Noble AR (2008) Petroleum system of Indonesia marine and petroleum geology. Amsterdam: North Holland/American Elsevier, Netherland 25: 103-129.
9. Soetantri B, Samuel L, Nayoan GAS (1973) The geology of oilfields in north east java. Indonesian Petroleum Association, Indonesia, pp. 149175 .

\section{Your next submission with Juniper Publishers} will reach you the below assets

- Quality Editorial service

- Swift Peer Review

- Reprints availability

- E-prints Service

- Manuscript Podcast for convenient understanding

- Global attainment for your research

- Manuscript accessibility in different formats ( Pdf, E-pub, Full Text, Audio)

- Unceasing customer service

Track the below URL for one-step submission https://juniperpublishers.com/online-submission.php 